\title{
Jean-Jacques Rutlidge, La quinzaine anglaise à Paris, ou l'Art de s'y ruiner en peu de temps
}

\section{Paola Sosso}

\section{(2) OpenEdition}

1 Journals

\section{Édition électronique}

URL : http://journals.openedition.org/studifrancesi/8939

DOI : 10.4000/studifrancesi.8939

ISSN : 2427-5856

Éditeur

Rosenberg \& Sellier

\section{Édition imprimée}

Date de publication : 1 octobre 2008

Pagination : 463

ISSN : 0039-2944

\section{Référence électronique}

Paola Sosso, « Jean-Jacques Rutlidge, La quinzaine anglaise à Paris, ou l'Art de s'y ruiner en peu de temps », Studi Francesi [En ligne], 155 (LII | II) | 2008, mis en ligne le 30 novembre 2015, consulté le 14 janvier 2021. URL : http://journals.openedition.org/studifrancesi/8939 ; DOI : https://doi.org/10.4000/ studifrancesi.8939

Ce document a été généré automatiquement le 14 janvier 2021.

\section{(c) 9 (i) $\Theta$}

Studi Francesi è distribuita con Licenza Creative Commons Attribuzione - Non commerciale - Non opere derivate 4.0 Internazionale. 


\title{
Jean-Jacques Rutlidge, La quinzaine anglaise à Paris, ou l'Art de s'y ruiner en peu de temps
}

\author{
Paola Sosso
}

\section{RÉFÉRENCE}

JEAN-JACQUES RUTLIDGE, La quinzaine anglaise à Paris, ou l'Art de s'y ruiner en peu de temps.

Édition critique par Roland MORTIER, Paris, Champion, 2007, pp. 209.

1 Romancier, homme de théâtre, pamphlétiste, journaliste, essayste, Jean-Jacques Rutlidge (1741-1794) est l'un des nombreux polygraphes du XVIII siècle. Il appartient à une famille d'Irlandais jacobites attachés à la cause des Stuarts et réfugiés en France après la défaite de Jacques II. Après une première éducation bilingue, il étudie chez les Jésuites; il renonce ensuite à une partie de son héritage et, dans les années soixantedix, tente sa chance à Paris. En 1776 paraît La quinzaine anglaise, présentée comme une traduction de l'anglais d'un ouvrage du Dr Stearne: il s'agit en réalité d'un ouvrage qui, se démarquant des récits habituels de voyage à Paris, présente la capitale comme un lieu de perdition et un piège affreux pour le protagoniste, un riche aristocrate britannique. Le texte eut un grand succès aussi bien en France qu'en Angleterre: le récit, proche des mémoires, est divisé en quinze chapitres correspondant aux 15 jours de ce séjour désastreux.

2 La fiction a un évident caractère moralisant: le riche anglais naiff, type conventionnel dont la personnalité demeure assez indéterminée, se voit obligé de jouer aux cartes, boit copieusement, participe, inconscient, à une orgie. A signaler la huitième journée, dans laquelle le protagonsite se fait le paladin de Shakespeare contre les critiques de Voltaire (argumentation que Rutlidge reprendra par la suite, ce qui déterminera une forte prise de position de la part du philosophe de Ferney). D'une aventure à l'autre, les fonds de Milord ont enfin fondu, et il se trouve ruiné et trahi, outre que vérolé. La 
dégradation progressive s'achève par l'expérience de la prison, d'où Milord sort désenchanté.

3 Si le roman résiste mal à la tentation de la surenchère, il semble ouvrir la voie au roman balzacien dans sa dénonciation des maux profonds d'une société pourrie. Remarquons encore, en Appendice, la Suite de La Quinzaine anglaise où l'on relate un second voyage à Paris fait par un Milord mieux accompagné. Le texte présenté se base sur l'édition de Londres de 1786 ( ( ${ }^{\mathrm{er}}$ tome). 